\title{
Neoliberalism and trade unions in Britain
}

Steve Cushion*

https://orcid.org/0000-0001-9624-4672

\begin{abstract}
The Tories in England had long imagined that they were enthusiastic about monarchy, the church, and the beauties of the old English constitution, until the day of danger wrung from them the confession that they are enthusiastic only about ground rent.

$\operatorname{Karl} \operatorname{Marx}(1852)$.
\end{abstract}

\section{Factors behind the Referendum on Britain's membership of the European Union}

British politics has been utterly dominated for the last three years by the question of Britain's membership of the European Union (EU), so-called "Brexit". The country voted to leave the Eu by a slim majority in a referendum but as always with referenda, an apparently simple yes or no alternative was interpreted in many different ways. There were those who voted to leave out of alienation and dislike of the increasingly discredited political establishment. There was a "Left-Exit" campaign from a minority of the left in the Labour Party, the remains of the Communist Party and the main Trotskyist organizations which, while not greatly significant in terms of votes, caused a division amongst the active members of the trade union movement. However, the main thrust of the "Leave" campaign was a right-wing nationalism tinged with heavy doses of anti-immigrant racism that opposed free movement of labor and spoke of 
"reclaiming our borders". Since the referendum there has been a considerable increase in racially motivated aggression against immigrants and people of colour. Amongst Brexit supporters, there is also a nostalgia for Empire, a vague but persistent desire to "make Britain great again". The racism that comes from this position helped fuel the Brexit campaign, while the Labour Party and the trade unions have historically been reluctant to confront the nationalistic and racist implications of such a world view for fear of being thought "unpatriotic".

As well as its natural base in the nationalist petite bourgeoisie, Brexit won over a particular group of Labour voters who depend on welfare benefits, particularly pensions, as well as those who depend on the free healthcare provided by the $\mathrm{Na}$ tional Health Service (NHS) or who require social housing. They were won over by promises to protect what is left of the welfare state by restricting it to British citizens. These are people who are concerned by the number of people who they assume to be foreigners in hospital waiting rooms, while failing to notice the doctors, nurses and other health workers from all over the world, without whom the National Health Service would collapse. The right wing press has long been full of horror stories about foreigners "abusing the health service", getting "priority for housing" or "sponging off the benefit system", mainly untrue and all wildly exaggerated. This has led to the common assumption that, without free movement of labour there will be more housing, jobs and social services for British nationals, for "our people".

Free movement of labour within the European Union was conceived of as a mechanism which was intended to level out the incomes of those living in poorer countries until different regions of the EU enjoy comparable living standards. Working class and petit bourgeois racists as well as neoliberal capitalists both object to free movement of labour, but for very different reasons. The ordinary racist in the street, as well as just hating foreigners, sees immigrants as accepting lower wages and as competition for jobs. The neoliberal capitalist has no objection to immigration as such, it is rather that they wish to control it so that they can obtain the labour they require as cheaply as they can and with as few rights as possible, thus the constant talk of an "Australian Points System", where immigration is tailored entirely to the needs of business ${ }^{1}$.

1. Australian working visas are most commonly granted to skilled workers. Candidates are assessed against a points-based system, with points allocated for certain standards of education. These visas are often sponsored by individual States, which recruit workers according to specific needs. Visas may also be granted to applicants sponsored by an Australian business. 
The origins of Neoliberalism lie in early 1920s, in the works of Austrian economist and sociologist Ludwig von Mises, as a response to the powerful organizations of German and Austrian workers (Mises, 1981, 1983, 2005). It represented a means of justifying the concentration of capital, the subordination of the state to the market and an anti-socialist system of social control. Mises became economic advisor to the Austrofascist dictator Engelbert Dollfuss. He argued for corporate tax cuts, balanced budgets, wage cuts and the repression of trade unions. He believed that Mussolini's seizure of power had "saved European civilisation. The merit that Fascism has thereby won for itself will live on eternally in history". Moreover that "the capitalistic market economy is a democracy, in which every penny constitutes a vote". Elected by means of what he called a "consumer plebiscite", the rich depended on the "will of the people as consumers" (Slobodian, 2018).

While such a programme could be very attractive to capitalists, particularly in the financial services sector, it would have no great appeal to the mass of the population in any half-way democratic society. However, right wing politicians quickly realised that they could attract support for the neoliberal agenda by "playing the race card" as Margaret Thatcher had done when she spoke of British people fearing they might be "rather swamped by people with a different culture" (Thatcher e Burns, 1978). Thatcher's election allowed her to pursue a policy of progressively trapping the trade unions in ever more restrictive and complicated regulations and legislation.

The Conservative Party learnt a very salutary lesson in 1972 when five shop stewards in the London docks were imprisoned for breaching a court order. This lead to massive unofficial strike action and the, normally moderate, Trades Union Congress (TUC) called a one-day general strike. The government climbed down and found a legal excuse to release the so-called "Pentonville 5". Thereafter, the basic principle of British anti-trade union law has been to avoid direct penalties on workers, but rather to threaten the funds of trade unions that do not obey the law to the letter. This drives the trade union bureaucracy to protect its assets by making sure that their members only engage in lawful industrial action.

Neoliberal politicians make a big play of their opposition to regulations. However, they are quietly in favour of the maximum regulation of trade unions, particularly restricting their right to strike.

Successive governments have imposed increasingly draconian restrictions on the normal functioning of trade unions, in particular making it increasingly difficult to hold a legal strike. Currently, not only must a postal ballot be held, but ballots have to achieve at least a $50 \%$ turnout of eligible union members, with a majority 
voting in favour of strike action. In important public services - including in the health, education and transport sectors - an additional threshold of $40 \%$ in favour of industrial action from all eligible members must be met for the action to be legal. The Government website says: "Tougher ballot thresholds will reduce industrial action in important public services like transport, health and education by $35 \%$, and 1.5 million working hours a year will be saved from strike action. These measures will provide a $£ 100$ million boost to UK economy over 10 years" (Department for Business, Energy e Industrial Strategy e James, 2017). Thus, in the current British university strike organized by the University and College Union (UCU) over pay and pensions, nearly all UCU branches voted in favour of taking action, but only about half managed to get the required 50\%. Another example of the way in which the regulations inhibit collective action can be seen in the present postal workers' dispute. Their trade union, the Communication Workers' Union (CWU) complied with the law in sending ballots to each individual member's home by post, but the workers brought their ballot papers into work where they held workplace mass meetings in which the issues were discussed, and then all filled out their ballot papers and posted them collectively. They voted overwhelmingly in favour of national strike action with a yes vote of $97.1 \%$ with $75.9 \%$ taking part in this ballot (Communication Workers' Union, CwU, 2019). The employer took legal action against the union and the judge ruled that CWU officials broke the rules for a postal ballot of the union's members, which stipulate the process should take place in the privacy of their own homes without interference by the union. This prevented the union taking legal strike action during the busiest period of the year for postal services, in the lead up to Christmas, as well as during the general election, thereby depriving the workers of maximum leverage. Of course they can reorganize their ballot but will have lost their best opportunity for victory. According to government's code of practice on industrial action, unions are required to give employers a week's notice of their intention to ballot, after which seven days is the minimum period for members to vote. If workers back action the union must then give 14 days' notice to the employer ahead of the strike (Jolly, 2019). As is evident, since the 1980s a core element of British trade union law has been deliberately complicated and restrictively interpreted by the judiciary to the benefit of employers.

Clearly, the promised "Bonfire of Regulations" only applies to removing restrictions on capital.

The United Kingdom allows foreign residents to hold their funds offshore and only taxes them on money they bring into the country. Once their funds are in London, a sophisticated legal and financial apparatus arranges for foreign funds to be deposited in a network of offshore jurisdictions that links the Channel Islands, 
the Isle of Man and the British territories in the Caribbean. Deregulation brought foreign banks to London and the City of London's particular neoliberal attitude to financial regulation and low tax, combined with the easy relationship with the British offshore jurisdictions, enables the banking sector to make the maximum profit for themselves and their clients. The financial sector, the intelligence community and the political parties are committed to a project that the mass media rarely mentions (Shaxson, 2012). The EU, which favours reasonably strong regulation in areas such as data privacy, tax avoidance, finance, climate and the environment, has driven the more extreme neoliberal wing of the Conservative Party to support for Brexit, backed by the financial services industry who have turned the UK into an off-shore centre for money laundering.

Right wing opposition to the European Union and its vision of the role of the State

Conservative opposition to the European Union developed during the Thatcher government of the 1980s. Before this it had been the centre right who campaigned for the UK to join. However, in September 1988, the President of the European Commission, Jacques Delors, addressed the annual conference of the British Trades Union Congress (TUC), setting out the Commission's proposals for a dialogue between employers and unions. He promised that future European Treaties would include, "The establishment of a platform of guaranteed workers' rights, containing general principles, such as every worker's right to be covered by a collective agreement and more specific measures concerning, for example, the status of temporary work" (MacShane, 2016, p. 67; Palmer, 1987). This effectively swung the majority of the trade union movement to support for the EU (Renton, 2019, pp. 70-73).

Margaret Thatcher's response was her Bruges Speech, in which she said "We have not successfully rolled back the frontiers of the state in Britain, only to see them reimposed at a European level with a European super-state exercising a new dominance from Brussels" (Thatcher, 2013, p. 656). The neoliberals in the Conservative Party did not object to the single market, but rather opposed the social policies that accompanied it such as the 48-hour week, equal treatment of part-time and full-time workers and equal pay between men and women. Such policies tended to increase the bargaining power of labour at the expense of capital, just as Thatcher was successfully reducing the UK's social wage (Harris, 2008, pp. 199, 249).

A split in the Conservative Party between its pro- and anti-EU wings finally forced Thatcher out of office and, indirectly gave birth to Ukip (United Kingdom Independence Party) in 1991, a virulently right-wing, racist, anti-European party, led by Nigel Farage. Farage confirmed his neoliberal credentials when the 1997 
Ukip manifesto said "Regulations destroy jobs and the Ukip is determined to reduce the regulatory burden on industry and on small businesses in particular" (United Kingdom Independence Party, 1997). Since then Farage has used Ukip, and latterly the Brexit Party, to pull the Conservative Party to the neoliberal right by threatening to attract their voters.

In 2012, a group of Conservative Members of Parliament published a book entitled Britannia Unchained that argued that that the UK has a "bloated state, high taxes and excessive regulation". It continues: "The British are among the worst idlers in the world. We work among the lowest hours, we retire early and our productivity is poor".

It went on to argue that businesses are deterred from recruiting staff because of employment laws which should be repealed (Kwarteng, Patel, Raab, Skidmore e Truss, 2012).

Writing in the Financial Times, senior Conservative politician Liam Fox wrote:

To restore Britain's competitiveness we must begin by deregulating the labour market. Political objections must be overridden. It is too difficult to hire and fire and too expensive to take on new employees. It is intellectually unsustainable to believe that workplace rights should remain untouchable while output and employment are clearly cyclical (Fox, 2012).

This view of the role of the state reduces it to Army, Police and Prisons. However, it is recognized that there is a limit to how deep a cut in welfare spending will be tolerated without threatening the alliance between racist workers, the enraged, nationalist petite bourgeoisie and neoliberal capital. Moreover, a modern capitalist economy requires a certain level of infrastructure, such as roads, electricity and so on, which are too important to the interests of the capitalist class as a whole to merely rely on market forces.

As Michel Foucault put it:

What is at issue is whether a market economy can in fact serve as the principle, form, and model for a state which, because of its defects, is mistrusted by everyone on both the right and the left, for one reason or another.

The problem of neo-liberalism is [...] how the overall exercise of political power can be modeled on the principles of the market economy. Its goal is "privatized social policy".

For neoliberalism free competition, reinterpreted to embrace monopoly power and vast inequalities, was the governing principle (Foucault, 2008, pp. 116-118, 131, 145).

The acceptance, even welcoming, of large monopoly corporations, which earlier, old-fashioned liberalism sought to restrict, has provided a solution to the dilemma of 
the need for state action; if public money needs to be spent, let it be spent outsourcing the work to large capitalist corporations. This will both be ideologically acceptable, as there is supposed to be competition in the process of bidding for contracts, as well as transferring public money from state expenditure into the profits of private corporations. Profits then go to the very neoliberal capitalists who are advocating the policy.

A few enormous corporations have emerged that depend on public expenditure for much of their revenue. Capita is the largest outsourcing and professional services company in the UK, with an overall market share of $29 \%$ in 2016, and has clients in central government, local government and the private sector. It also has a property and infrastructure consultancy division which is the fourth largest in the UK. Roughly half of its turnover comes from the public sector. There are repeated scandals about Capita and other outsourcing corporations, but there is very little sustained criticism, in part because most politicians and journalists accept the need for outsourcing and cannot conceive of bringing these services back into public ownership.

Almost three-quarters of companies which have been given major government contracts have operations based in tax havens, according to a new report from the social democratic thinktank, Demos. Twenty-five of the government's 34 strategic suppliers, organizations that receive $£ 100$ million or more in revenue, operate in offshore centres. The Labour peer, Lord Haskel, added: "For too long large international tech companies have failed to pay their fair share of tax while being rewarded with government contracts, leaving British companies at a competitive disadvantage". Rose Lasko-Skinner, co-author of Value Added wrote "Government procurement could be an incredible force for good in the UK, beyond the public sector and in the economy more broadly". These two comments indicate the maximum criticism that the press will publish or politicians will make. While complaining about the manner in which outsourcing is organized and proposing reforms, the basic neoliberal agenda is unchallenged. Meanwhile the trade unions, which one would have thought to have an interest in returning as much as possible to state ownership, have largely failed to confront the outsourced companies at national level.

Trade union resistance to deregulation and global monopolies

The trade unions have, generally speaking, not responded well to the political and industrial changes that have taken place in Britain over the last 25 years. Most union structures are still based on the large, well organized workplaces that no longer exist because of outsourcing, automation and the transfer of production to lower cost regions of the world. To give an example, the Ford Motor Company, which 
once employed 30,000 workers in its Dagenham plant in East London, is currently down to 4000 employees and is threatening more job cuts. Yet Unite the Union, an amalgamation of the old Transport and General Workers Union (TGWU) and the Amalgamated Union of Engineering Workers (Auew), still has a structure based on trade groups that used to conduct national bargaining, even though such national agreements are largely a dead letter in the current climate. In the 1980s and 90s, many unions thought they could halt the decline in membership numbers by stressing the services they supplied, such as insurance. This did little to stop the membership erosion, but at the same time undermined the old assumptions of solidarity.

One of the more imaginative initiatives from Unite has been their "Community Branches", set up to organize the unemployed, pensioners and the self-employed. These have become, in some areas, an organizing structure enabling unemployed and retired left wing militants to continue to campaign against government policies of austerity and to provide solidarity with striking workers. But this is a minor initiative with only local significance.

Thirty years ago, there was still a rank and file, shop steward based workers' movement. Of course there were some local union representatives who were sucked into an accommodation with management, but with regular union elections, it was never long before a reform candidate would stand for election and remove them. Local shop stewards would frequently call unofficial walk-outs and gain small victories, thereby giving even moderate workers a good reason to join the trade union. However, a combination of pressure from the union bureaucracy to obey the law, the privatisation and division of large publicly owned corporations, outsourcing and the closing of many of the industries which employed large numbers of industrial workers, all combined with vastly increased bullying from human resource management, has largely broken this movement.

Equally, the large general unions have not been particularly successful in opposing zero-hour contracts, flexible working and bogus self-employment, the so-called "gig economy", which has further reduced the rights of workers. This did not have to be so, for where these forms of hyper-exploitation have been opposed, workers have responded. Members of the Public and Commercial Services Union (PCS), the main civil service union, who work as caterers, cleaners, security guards, porters, reception and post-room staff in the government's Business, Energy and Industrial Strategy (Beis) Department, but who are employed by the outsourcing corporations Aramark and Iss, waged a long campaign followed by solid, indefinite strike action. This ended with deals giving them the London Living Wage of $£ 10.55$ an hour, as well as improved holiday and sickness absence conditions and other improvements ("Power in our Union", 2019). 
A small, largely anarcho-syndicalist led union, the Independent Workers of Great Britain (IWGB) has had some success organizing these marginalized, often immigrant workers, particularly Uber taxi drivers and the outsourced cleaning and security staff at the University of London. This last group have shown considerable energy and used innovative tactics. They are currently calling for a boycott of academic activity in the main London University building, Senate House, and have succeeded in gaining support from many academic staff as well as from the University and Colleges Union (UCU) annual congress.

UCU also had a long and successful dispute last year over attempts to reduce the retirement benefits available from the pension fund. This was a remarkable dispute that involved a very militant response from a sector not previously known for its militancy, indeed many would have considered university professors far too "middle class" for such action. The strike was organized on the basis of one day the first week, two the second until it became an indefinite action. During the dispute, the union recruited over 30,000 new members. Each branch held a mass meeting at midday every day, so when the union's General Secretary tried to sell a compromise deal, nearly every branch had rejected it by 4pm the same day and 1000 lecturers demonstrated outside the union's head office the following morning as the General Secretary arrived. As a result, the strike continued and a positive settlement was arrived at. Now, a year later, management have reneged on the deal and the strikes have started again.

In some ways, this reflects the changing nature of the British economy. The mines are nearly all closed, ship-building is practically finished, textiles are all made in Asia, most of the car factories have exported production to lower waged countries, while in those that remain the robots outnumber the human beings. This frequently leaves the university as the largest employer in a town and the increased militancy of the university employees can be seen as a reflection of their greater economic importance. Equally, as universities use increased student fees to become large capitalist corporations, they have become plagued with modern human resource management techniques such as short-term and zero-hours contracts, as well as increased bullying. This has added to the anger and militancy of academic staff.

The other union which has maintained a strong organization is the National Union of Rail, Maritime and Transport Workers (RMT). They have fought long and bitter campaigns to save the jobs of ticket office clerks and train guards. The previous RMT General Secretary, Bob Crow, was a hate figure to the right wing media, who assumed that the militancy of the railway workers was purely as a result of his leadership. The government could barely conceal its glee when he died of a heart attack and welcomed the election of his allegedly more moderate successor. Subse- 
quent strikes and a continuation of previous policies showed that there is still a high level of rank and file organization. So, in the 2019 election campaign, the leader of the Conservative Party announced his intention to bring a new law demanding that railway unions guarantee a certain level of service during strike actions. If they do not do so, the strikes will be considered unlawful (Swinford e Zeffman, 2019).

The pattern here seems to be that the smaller, single industry, trade unions organizing workers in sectors that are still essential to the neoliberal economy have proved more capable of resisting the employers' offensive than the big general unions that have protected their bureaucratic structures by amalgamating with other unions in a similar position. However, in some localities, militants have been able to use the larger unions as a structure within which they can organize small groups of workers. The leadership of these large general unions has, however, generally given up on direct industrial action and placed their faith in the election of a Labour government. This strategy is threatened by the question of membership of the European Union, which is largely dominating the debate in the current election campaign, submerging the more class-based policies, such as defense of the health service, on which the Labour Party is strongest.

\section{Divisions among the political parties about membership of the European Union}

The Labour Party, to which the majority of trade unions are affiliated, took the official position during the referendum to urge their supporters to vote to remain in the EU, but there was a substantial minority of party members who wanted to leave. However, the manner of campaigning reflected the left-right split in the party, the right-wing supporters of the previous Labour leader, Tony Blair, and the majority of the Members of Parliament arguing a pro-business case for continuing EU membership that alienated many workers. It is interesting that Blair has gone back to that strain in the origins of neoliberalism that, following Friedrich Hayek, conceded the need for a social safety net but only on condition that an interstate federation was in place to limit its growth, an authority above the nascent welfare state, with the power to say no (Zevin, 2019). On the other hand, the more nuanced arguments in favour of "Remain" made by the majority of members who support the current leader, Jeremy Corbyn, tended to be submerged in the face of the nationalist onslaught from the extreme right.

Jeremy Corbyn became the leader of the Labour Party in a quite unexpected manner when, in order to give themselves more credibility, the party bureaucracy widened the right to vote to supporters who paid a one-off fee. His campaign, a "clear anti-austerity platform" which included scrapping the Trident nuclear weapons 
system and withdrawal from Nato as well as establishing a national investment bank to boost house-building and improve economic growth and lift wages in areas that had less investment in infrastructure through restoring the 50p top rate of income tax, struck a chord with many rank-and-file activists and recruited thousands of new members.

Corbyn is by far the most left-wing leader of the Labour Party for 40 years. Since his election he has faced deep and relentless hostility from the party establishment, who have done all they can to undermine him, so far unsuccessfully, but their constant criticism has taken its toll. The particular tactic the right-wing of the Labour Party has adopted is to make exaggerated accusations of antisemitism against left wing figures in the party, while alleging that Corbyn has tolerated if not encouraged this. This, in part, is done by equating support for the rights of the Palistinian people with antisemitism and even suggesting that anticapitalism is antisemitism ${ }^{2}$. This has been a serious distraction that has undermined the confidence of many party members and wasted effort that could have been used campaigning against the Conservative government, but it is evident that the Blairite wing of the party would rather lose an election than see Corbyn as Prime Minister.

However, these divisions are nothing compared to the split in the Conservative Party. Both sides reflect different interpretations of neoliberalism. The "Remain" tendency take a similar attitude to that of Tony Blair described above, seeing the European Union as a useful way of keeping excessive social spending in check and representing that section of the capitalist class that profit from free trade within $\mathrm{Eu}$ rope. But we must not forget that the European Union itself is a neoliberal project, as shown by the treatment of Greece under an EU imposed austerity regime for the benefit of the German banks. Increased competition is the key to all EU decisions, but competition on what is referred to as a "level playing field". The militancy of the French workers and the negotiating strength of the German trade unions have kept certain EU workers' rights at a higher level than the "Leave" tendency of British capitalism would wish.

This "Leave" tendency represents a more extreme version of neoliberalism that sees the state as a means of laundering public money into the hands of their big business supporters and considers all regulation of capital as unwarranted interference. Their backers come from the more disreputable end of the financial services industry, which makes its profits by managing the ill-gotten gains of Russian oligarchs and Saudi princes, as well as from the petrochemical industry and the arms manufactur-

2. Siobhain McDonagh, Labour $\mathrm{mp}$ for Mitcham and Morden, linked antisemitism and anticapitalism in an interview on BBC Radio 4, March 4th 2019. 
ers who are most afraid of state regulation. This "Leave" group, by their embrace of racist nationalism, has gained control of the Conservative Party and either purged or driven out the main Conservative "Remainers" and bullied the moderates into compliance. Twenty-three Conservative Members of Parliament, including a number of ex-ministers, have been expelled from the party.

The Prime Minister, Boris Johnson, vowed to take Britain out of the EU in October, whether or not there is an agreement to replace the previous trade relations. It is widely recognised that such a "No-Deal Exit" would be economically disastrous, but the government ignored this, using a variety of blatantly undemocratic manoeuvers to attempt to overcome the fact that it no longer had a majority in Parliament. When this failed, Johnson forced a general election, intending that the only real issue should be, as the Conservative election slogan would have it, to "get Brexit done".

\section{Challenges to the neoliberal agenda}

One issue that is threatening to take attention away from this strategy is the question of climate change. Despite some apparently well meaning talk of planting millions of trees, Conservative Party policy is based on the neoliberal principle that it is the market and individual action that can save the planet, while opposing government intervention and regulation. Stopping fracking three weeks before the election was a blatant vote-grabbing stunt, which will inevitably be rescinded now the Conservative Party has been re-elected with substantial majority. Even the half-hearted efforts of the European Union to combat global warming are too much for the energy companies.

Yet clearly personal efforts by consumers will be woefully insufficient to keep global warming under $1.5^{\circ} \mathrm{C}$. We shall need to take railways and utilities and energy grids back into public control; regulate corporations to phase out fossil fuels; and raise taxes to pay for massive investment in climate-ready infrastructure and renewable energy. This is one area where trade unions have made serious strides forward. Last year's TUC congress called for urgent action to achieve a just transition to a net zero economy. This is a considerable advance on previous congress inaction where the union's organizing workers in the energy sector and other highly polluting industries managed to gut the resolutions on climate changed in the short term interest of saving their members' jobs. Moreover, the idea of a "just transition" is gaining credibility. As the Campaign against Climate Change Trade Union Group argue:

We can create a million secure Government jobs in renewable energy, in increasing energy efficiency by insulating homes and public buildings free of charge, in hugely expanding cheap 
public transport to get people and freight onto cleaner forms of transit, and in developing the "green skills" that we need through education and training.

A million decently paid Government jobs, and the spin-off of half a million additional jobs that this would create, could kick-start the economy. It is the alternative both to austerity and to Government inaction as the world slides towards climate catastrophe. (Campaign against Climate Change Trade Union Group, 2014).

Such an approach is a direct affront to the neoliberal agenda. Mass action by young people in recent years, particularly the school student strikes, has clearly had an effect on the trade union movement, to the extent that, this year, the TUC called for industrial action to support for the school students. The response was limited but positive and showed that this is an area where trade unions could regain the initiative and relate to youth. At the time of writing, UCU is engaged in more strike action to defend their members' pension scheme and seeking a wage rise. The London Regional Committee of the union has linked these issues with climate change, organizing a demonstration for "Pay and Planet".

The other issue which threatens the neoliberal agenda is the question of the National Health Service (NHS). The NHS is widely recognised as the most popular institution in the country, with wide recognition of the degree to which the overwhelming majority of people are dependent on it for healthcare. Even the most ardent neoliberals are keen to deny that they are privatizing the system, as in the Conservative Party's recent claim, made in purchased Google advertisements, that "the NHS is not for sale - and it never will be". Yet research commissioned by GMB, one of the unions that organizes NHS workers found that:

- The value of identified outsourcing contracts awarded to private companies almost doubled from $£ 1.9$ billion in 2015 to $£ 3.6$ billion in 2018 , the most recent full year for which figures are available (an increase of 89 per cent).

- NHs contracts worth $£ 3.6$ billion were awarded to private companies in 2018 an increase of 20 per cent on the year before.

- So far in 2019 private companies have won NHS outsourcing contracts worth $£ 3.3$ billion (GMB Union, 2019).

The neoliberal justification for such outsourcing is increased efficiency, but trade unions point out that the main way private companies achieve "efficiency savings" is through cutting staff wages. This has been resisted and we not only see traditional trade unions taking a more combative stance, but also many of the old professional associations are behaving more and more like trade unions. The Royal College of 
Nursing affiliated to the Trades Union Congress in 2015 and, the following year, the British Medical Association called a series of strikes of junior hospital doctors to resist a new contract. Where traditional health service trade unions have proved too moderate, workers have sometimes shown themselves prepared to move to other unions, ironically a right given to them under Conservative anti-trade union legislation. Thus, for example, the mainly immigrant cleaners, porters and catering staff in Barts NHs Trust, which covers four large hospitals in North London, left their previous union, Unison, a mass and joined Unite, which supported them in 24 days' strike action in 2017, winning a significant pay increase.

Perhaps the largest sums of public money that have been laundered from the public sector to private corporations are via the procedure known as Public-Private Partnerships or Private Finance Initiatives (PFI). Under a private finance initiative, the private company handles the up-front costs instead of the government. The project is then leased to the public, and the government authority makes annual payments to the private company at extortionate rates of interest. These contracts are typically given to construction firms and can last as long as 30 years or more. For example, a PFi contract awarded last year by St Helens e Knowsley Teaching Hospitals NHs Trust was worth half a billion pounds ( $\$ 500$ million). New research from the Centre for Health and the Public Interest (CHPI) shows just how much these debts are hurting the NHs.

Analysis of accounting data from the Treasury and Companies House for the period 2010 to 2015 finds:

- Over the past 6 years, companies which run PFI contracts to build and run NHS hospitals and other facilities have made pre-tax profits of $£ 831 \mathrm{~m}$ - money which has thereby not been available for patient care over this period.

- If the NHs had not been paying profits on PFI schemes, deficits in NHS hospitals would have been reduced by a quarter over this 6 year period.

- Over the next 5 years, almost $£ 1$ bn of taxpayer funds ( $£ 973 \mathrm{~m})$ will go to PFI companies in the form of pre-tax profits - equivalent to a quarter $(22 \%)$ of the additional amount of money $(£ 4.5 \mathrm{bn})$ that the government has promised the NHS over this period.

- A number of PFI schemes are generating particularly high pre-tax profits for their operators. The company which holds the contract for the hospital at University College London has made pre-tax profits of $£ 190$ m over the past 11 years out. This is out of $£ 527 \mathrm{~m}$ paid to the company by the NHS. The total value of the hospital is $£ 292 \mathrm{~m}$ (Centre for Health and the Public Interest, CHPI, 2017). 
One of the main outsourcing companies in the health sector, Virgin Healthcare, took the NHS to court in 2016 after it failed to secure an $£ 82$ million contract to provide children's health services in Surrey, winning an undisclosed sum in an out of court settlement. This use of the law to demand compensation for profits to which a company considers itself entitled, which is a factor in many international trade treaties, is now penetrating domestic legislation. In the debate over Brexit, the Conservative Party has loudly trumpeted the advantages of a free trade deal with the USA, but a leaked secret document about the ongoing trade talks between the UK and USA, contains proposals by US negotiators for a 'corporate court system' that would allow big business to sue the British government, in secret and without appeal, for anything they regard as 'unfair'. Recent similar cases have included suing governments for trying to phase out the use of $\mathrm{coal}^{3}$.

Clearly the us pharmaceutical industry wants the NHS to be part of any future trade deal between the two nations. In particular us officials are making a further threat to the NHS in terms of medicine pricing policy, with special concern about paying more for cancer medicines, for which Big Pharma feels Britain does not pay enough. Trade negotiators have received special lobbying from pharmaceutical corporations as part of the trade talks.

The future of the working class under the conservative government: December 2019

\begin{tabular}{cccccc}
\hline Conservative & Labour & $\begin{array}{c}\text { Scottish } \\
\text { Nacional Party }\end{array}$ & $\begin{array}{c}\text { Liberal } \\
\text { Democrat }\end{array}$ & $\begin{array}{c}\text { Democratic } \\
\text { Unionist Party }\end{array}$ & Others \\
\hline 365 & 203 & 48 & 11 & 8 & 15 \\
+47 & -59 & +13 & -1 & -2 & +2 \\
\hline
\end{tabular}

On 13 December 2019, a Conservative Government was elected with a substantial majority under Prime Minister Boris Johnson on a program of the UK withdrawing from membership of the European Union. Johnson is committed to deregulation, removing all restrictions on global corporations, the banking sector and financial services. He is explicit about restraining the unions from taking lawful strike action to protect wages and conditions. His government will be authoritarian and anti-working class: the promises of investment in jobs, health, housing, infrastructure and education is unlikely to materialise in ways which will benefit the working class, if they are delivered at all. We need to remember the origins of neoliberalism in Vienna under Dolfuss and the attacks made on organizations of

3. Global Justice Now: https://www.globaljustice.org.uk/. 
the working class and its consequences. Unions will need to directly challenge laws which restrict action by their workers to protect wages and working conditions: unions will need to reconsider their relationship to the Labour Party which was abandoned by voters caught up in the rising swell of nationalism and who voted against their own class interests.

\section{References}

Campaign against Climate Change Trade Union Group. (2014), "One million climate jobs: tackling the environmental and economic crisis”. Available at https://www. campaigncc.org/climatejobs.

Centre for Health and the Public Interest (chpi). (2017), P.F.I. Profiting from Infirmaries.

Communication Workers' Union (cwu). (2019), “Postal workers deliver record yes vote for national strike action”. UK Government Press Release, CWU Press Release. Available at https://www.cwu.org/press_release/postal-workers-deliver-record-yes-vote-for-nationalstrike-action/.

Department For Business, Energy \& Industrial Strategy \& James, Margot. (2017), "Trade Union Act measures come into force to protect people from undemocratic industrial action", UK Government Press Release. Available at https://www.gov.uk/government/ news/trade-union-act-measures-come-into-force-to-protect-people-from-undemocraticindustrial-action.

Foucault, Michel (2008), The birth of bio-politics. New York, Palgrave Macmillan.

Fox, Liam. (2012), “The pressing case to cut both taxes and spending”. Financial Times.

Global Justice Now, https://www.globaljustice.org.uk/.

GMB UNION. (2019), "Privatisation of NHS contracts worth $£ 15$ bn since 2015 - new research". GMB Press Release. Available at https://www.gmb.org.uk/news/privatisation-nhs-contracts-15bn. HARris, R. (2008), Ralph Harris in his own words, London, IEA.

International Chamber of Commerce. (1949), The International Code on Fair Treatment for Foreign Investments.

JoLLY, Jasper. (2019), “Royal Mail wins high court injunction to stop postal strike”. The Guardian. Available at https://www.theguardian.com/business/2019/nov/13/royal-mail-wins-highcourt-injunction-to-stop-postal-strike.

Kwarteng, K.; PAtel, P.; RaAb, D.; Skidmore, C. \& Truss, E. (2012), Britannia unchained: global lessons for growth and prosperity. London, Palgrave.

MacShane, Dennis. (2016), Brexit: how Britain left Europe. London, I. B. Tauris.

Mises, Ludwig Edler von. (2005), Liberalism: the classical tradition. Indianapolis, Liberty Fund. 
Mises, Ludwig Edler von. (1983), Nation, state, and economy: contributions to the politics and history of our time. Indianapolis, Liberty Fund.

Mises, Ludwig Edler von. (1981), Socialism: an economic and sociological analysis. Indianapolis, Liberty Fund.

PAlmer, John. (1987), Europe without America: the crisis in Atlantic relations. Oxford, Oxford University Press.

"Power in our union". (2019), PCS People, 3: 1-2. Available at https://www.pcs.org.uk/sites/ default/files/site_assets/pcs_people/2019/p1_16_PCSPeople_Issue3.pdf.

Renton, David. (2019), The new authoritarians: convergence on the right. London, Pluto Press.

Shaxson, Nicholas. (2012), Treasure Islands: tax havens and the men who stole the world. London, Vintage.

SLOBODIAN, Quinn (2018), Globalists: the end of empire and the birth of neoliberalism. Cambridge, Massachusetts, Harvard University Press.

Swinford, Steven \& ZefFman, Henry. (2019), "Conservative policies: Tories would force rail unions to run services during strike”. The Times. Available at https://www.thetimes. co.uk/article/conservative-policies-tories-would-force-rail-unions-to-run-services-duringstrike-6txscfdn8.

Thatcher, Margaret. (2013), The autobiography. London, Harper Press.

Thatcher, Margaret \& Burns, Gordon. (27), "Tv interview for Granada World in Action". Granada $T V$.

United Kingdom Independence Party. (1997), Manifesto.

Zevin, Alexander (2019), "Every penny a vote". London Review of Books, 41 (16). Available at https://www.lrb.co.uk/the-paper/v41/n16/alexander-zevin/every-penny-a-vote.

\section{Abstract}

\section{Neoliberalism and trade unions in Britain}

For the past 30 years, Britain's ruling class has been deeply split over membership of the European Union. This came to a head over the referendum on so-called "Brexit". The Conservative Party (Tories) was split into "Remain" and "Leave" wings, both neoliberal, but with a different interpretation of the best way to make profits for the section of British capitalism each represents. Meanwhile the Labour Party is divided between the pro-business, neoliberal wing and the social democratic, reformist wing. The trade unions, with one or two notable exceptions, have conducted their activities within the parameters of parliamentary politics and desperately hoped for a Labour victory. The recent general election gave complete victory to the "Leave" Tories, which is potentially disastrous for the trade unions and their members.

Keywords: Neoliberalism; Trade Unions; Britain; Brexit. 


\section{Resumo}

\section{Neoliberalimo e sindicatos na Grã-Bretanha}

Nos últimos trinta anos, a classe dominante britânica sofreu uma profunda divisão em relação à questão da Grã-Bretanha fazer ou não parte da União Europeia. A divisão culminou no referendo do chamado "Brexit". O Partido Conservador (Tories) se dividiu entre os favoráveis à permanência e os favoráveis a deixar a União Europeia, duas alas neoliberais com interpretações diferentes sobre a melhor maneira de conquistar lucros para a seção do capitalismo britânico que cada uma representa. O Partido Trabalhista se dividiu entre a ala neoliberal, favorável aos negócios, e a ala reformista, social democrata. Os sindicatos, com uma ou duas notáveis exceções, conduziram suas atividades conforme os parâmetros da política parlamentar e ansiaram, desesperadamente, uma vitória trabalhista. A recente eleição geral deu vitória total aos Tories, favoráveis a deixar a União Europeia, o que é potencialmente desastroso para os sindicatos e seus membros.

Palavras-chave: Neoliberalismo; Sindicalismo; Grã-Bretanha; Brexit.

Texto recebido em 16/12/2019 e aprovado 2/1/2020.

DOI: 10.11606/0103-2070.ts.2020.165088.

STEVe CuShION is retired university lecturer living in East London. He is Secretary of the University and College Union (UCU), London Retired Members' Branch. E-mail: s.cushion23@ gmail.com. 